\title{
Optimization of Nitrogen Fertilization Input on Zea mays L. Cultivation through the Biological Inhibition of Nitrification
}

\author{
Purwanto, S. Minardi, Supriyadi \\ Soil Science Department, Agriculture Faculty, Sebelas Maret University, Surakarta, Indonesia \\ Email: purwahadi.ph@gmail.com
}

Received 19 January 2015; accepted 2 February 2015; published 6 February 2015

Copyright (C) 2015 by authors and Scientific Research Publishing Inc.

This work is licensed under the Creative Commons Attribution International License (CC BY). http://creativecommons.org/licenses/by/4.0/

(c) (i) Open Access

\begin{abstract}
Introduction: Nitrogen (N) fertilizer is the most widely used fertilizer $(300-350 \mathrm{Kg} / \mathrm{Ha})$ on the corn plant, mean while it has mobile character, so it becomes the lowest utilization $(40 \%-50 \%)$ compared to other nutrient elements. Aims: The aim of this research is to examine the effect of various qualities and dose of litter on the dynamics of $\mathrm{N}$ mineral soil and soil nitrification potential on maize cultivation system. Method: The treatment is set by Randomized Completely Block Design (RCBD). Four kinds of litter is chosen to represent the groups of low quality (Tectona grandis and Pterocarpus indicus) and the groups of high quality (Oryza sativa and Eupatorium inulifolium) are given on four doses: 4, 8, 12 and $16 \mathrm{mg} / \mathrm{Ha}$. All treatments are fertilized with urea 150 $\mathrm{kg} / \mathrm{Ha}$. Variables measured include the soil concentration of $\mathrm{NH}_{4}^{+}$and $\mathrm{NO}_{3}^{-}$, potential nitrification conducted in 2, 4, 6, 8 and 10 weeks after planting the corn. Result: The research shows that the addition of low-quality litter is influenced very significantly by release of $\mathrm{NH}_{4}^{+}$, formation of $\mathrm{NO}_{3}^{-}$and potential nitrification of soil. Others results show that the content of litter (lignin, polyphenol and $\mathrm{C} / \mathrm{N}$ ratio) has the most powerful influence as regulator of $\mathrm{NH}_{4}^{+}$released $(\mathrm{p}<0.01)$, the formation of $\mathrm{NO}_{3}^{-} \quad(\mathrm{p}<0.01)$ and potential nitrification of soil $(\mathrm{p}<0.01)$ rather than the content of lignin, polyphenol and $\mathrm{C} / \mathrm{N}$ ratio of litter separately. Conclusion: The conclusion of this research is that the management of litter quality input can be applied in the field to regulate the process of nitrification in soil and potential to increase $\mathrm{N}$ used efficiency of corn plant.
\end{abstract}

\section{Keywords}

Litter Quality, $\mathrm{NH}_{4}^{+}, \quad \mathrm{NO}_{3}^{-}$, Biological Nitrification Inhibition, Corn Plant 


\section{Introduction}

Nitrogen fertilizer is the most widely used fertilizer (300 - $350 \mathrm{~kg} / \mathrm{Ha}$ ) on the corn plant, but because it has mobile characterization, it becomes the lowest utilization (only 40\% - 50\%) compared to other nutrient elements [1]. Approximately-estimated $50 \%$ of the fertilizer $\mathrm{N}$ in wet tropical areas will be lost [2]. Although corn plants can absorb the $\mathrm{N}$ in the form of $\mathrm{NH}_{4}^{+}$and $\mathrm{NO}_{3}^{-}$, but $\mathrm{NH}_{4}^{+}$form is more efficient because it requires lower photosynthesis energy for reduced in $\mathrm{NH}_{3}$ i.e. $5 \mathrm{ATP}$ per $\mathrm{NH}_{4}^{+}$molecule, where as $\mathrm{NO}_{3}^{-}$requires 20ATP per molecule [3]. Inhibition of nitrification can increase the efficiency usage of photosynthesis so it can increase the dry weight of the plant. Proven that $\mathrm{N}$ uptake in wheat would increase by $35 \%$, if $25 \%$ of its fertilizer $\mathrm{N}$ was in the form of $\mathrm{NH}_{4}^{+}$[4]. It is expected that the optimization of nitrification can be developed with a variety of efforts such as the selection of the right litter, so as to achieve the welfare of the corn harvest.

Corn is one of the most important food crops after rice and wheat. Corn is the main source of carbohydrates and as an alternative source of food in some developed countries. Indonesian peoples also use corn as a staple food. Corn's cobs and leaves are also used as a source of carbohydrates for livestock. Corn's plants can also be taken its oil, made of flour or cornstarch and used as industrial raw material. Corn cobs have rich pentose. Genetically engineered corn has also been widely cultivated [5]. Because of the importance of this corn cultivation, it must continue to increase in yields and quality, so that it can improve the quality of human resource as a whole.

Nitrification is the oxidation process of $\mathrm{NH}_{4}^{+}$by successive chemoautotroph bacteria produce $\mathrm{NO}_{2}^{-}$and $\mathrm{NO}_{3}^{-}$. Bacteria of the genus Nitrosomonas and Nitrospira do nitrification with oxidize $\mathrm{NH}_{4}^{+}$become $\mathrm{NO}_{2}^{-}$, being bacteria of the genus Nitrobacter do nitrification with oxidize $\mathrm{NO}_{2}^{-}$become $\mathrm{NO}_{3}^{-}$[6]. Nitrification is considered as a detriment because in addition to lowering the efficiency of the utilization of $\mathrm{N}$ by plants, it also causes complex environmental problems. Through the nitrification that about $67 \%$ of the $\mathrm{N}$ fertilizer on various food crops in the world (equivalent to US 15.9 billion dollars/years) will be lost in the form of gases, $\mathrm{N}_{2} \mathrm{O}, \mathrm{NO}_{2}$, $\mathrm{NO}$ and $\mathrm{N}_{2}$, and or lost in the form of nitrate $\left(\mathrm{NO}_{3}^{-}\right)$to the sub soil layers that can't be reached by the plant roots [1]. The leaching of $\mathrm{NO}_{3}^{-}$will be followed by the leaching of base cations $\left(\mathrm{K}^{+}, \mathrm{Ca}^{2+}\right.$ and $\left.\mathrm{Mg}^{2+}\right)$ resulting in the lower base saturation and increase soil acidity. Factors affecting nitrification are nitrification bacteria populations, the availability of $\mathrm{NH}_{4}^{+}$, soil $\mathrm{pH}$, and the concentration of base cations, aeration, drainage, moisture, temperature, fertilizer salts as well as the presence of nitrification inhibitor compounds in soils [6] [7]. In developing countries being sought hinder nitrification use slow-release $\mathrm{N}$ fertilizer [8] or $\mathrm{N}$ fertilizer with nitrification inhibitors such as Thiourea, Sulfathiazole, Dyciandiamide, Etridiazole and N-serve [9]. Application of the synthetic nitrification inhibitor compound shows reduce the loss of soil $\mathrm{N}$ effectively, beside the price is expensive (relatively). It also has a detrimental effect on non-target microbes such as $\mathrm{N}_{2}$ fixers (diazotroph) bacteria and mycorhiza fungi [10]. The low potential of soil nitrification in mixed coffee farm is closely related to the diversity of litter quality in surface soil and soil organic content. This indicates that the input of organic matter quality regulate can inhibit nitrification rate, and increase the efficiency of $\mathrm{N}$ utilization [11]. The study is designed to optimize the $\mathrm{N}$ fertilizer inputs via biological control of nitrification on the corn plant by manipulating the dose and the quality of litter input (lignin and polyphenols content as well as $\mathrm{C} / \mathrm{N}$ ratio). By balancing the process of $\mathrm{N}$ immobilization and nitrification in soil, it is expected to optimize the utilization of $\mathrm{N}$ fertilizer inputs and to reduce $\mathrm{N}$ loss from the soil, so as to reduce the environmental impact.

\section{Method}

This research used a Randomized Complete of Block Design (RCBD). We used four types of litter materials selected based on their quality, i.e. lignin, polyphenol, $\mathrm{C} / \mathrm{N}$ content. Corn seeds use BISI 2 and soils use Alfisol.

Experimental plots were divided into subplots in $3 \times 1 \mathrm{~m}^{2}$ dimensions. The basis fertilizers are given simultaneously with the application of litter as a substrate of nitrification. Basis fertilizer dose calculated based on the results of preliminary analysis of soil and nutrient needs of corn crops. Given fertilizer was urea $(213.32 \mathrm{~kg} / \mathrm{Ha})$, SP 36 (437.81 kg/Ha), and KCl (237.68 kg/Ha). Planting corn spacing was $75 \times 25 \mathrm{~cm}^{2}$.

Soil samples for measurement of $\mathrm{NH}_{4}^{+}$and $\mathrm{NO}_{3}^{-}$taken at a depth of $0-10 \mathrm{~cm}$. Taken soil done intensity as minimum possible as to avoid change the composition of soil. Five grams of soil samples extracted with 20 $\mathrm{ml}$ of a KCL 3M solution, shake for 1 minute, add 2 drops of toluene to prevent mineralized and nitrification process, allowed to stand overnight, then filtered with a Whatman-42 filter paper [12]. The concentration of $\mathrm{NH}_{4}^{+}$and $\mathrm{NO}_{3}^{-}$was measured in The Laboratory of Chemistry and Soil Fertility, Faculty of Agriculture, Sebelas Maret University, using spectrophotometer on $\lambda 535 \mathrm{~mm}$ [13]. 
Soil samples for potential nitrification measurements taken by aseptic at a depth of $0-20 \mathrm{~cm}$. Nitrification potential was measured from the total of $\mathrm{NO}_{2}^{-}$formed of soil samples after add up with $\left(\mathrm{NH}_{4}\right)_{2} \mathrm{SO}_{4}$, and incubated at a temperature of $25^{\circ} \mathrm{C}$ for 5 hours [14].

The measurement variables of $\mathrm{NH}_{4}^{+}, \mathrm{NO}_{3}^{-}$, and potential nitrification done once every 2 weeks, which was in week $2^{\text {nd }}, 4^{\text {th }}, 6^{\text {th }}, 8^{\text {th }}$, and $10^{\text {th }}$ after the litter application. Corn seeds planted on day $2^{\text {nd }}$ after the litter application. The harvest was done in 13 weeks after planting with trim the corn cobs in advance. The data analyzed by analysis of variance test in SPSS for window 17.

\section{Results and Discussion}

\subsection{Doses and Quality of Litter}

Litter used in this research content of lignin, polyphenols, and $\mathrm{C} / \mathrm{N}$ ratio varies (shown in Table 1).

Litter decomposition rate is determined by the quality of litter or the content of soluble carbohydrates, amino acids, active polyphenols, lignin, as well as the $\mathrm{C} / \mathrm{N}$ ratio [15]. High quality litter categorized by ratios $\mathrm{C} / \mathrm{N}$ less than $25 \%$, lignin $<15 \%$, and polyphenols $<3 \%$ contents, thus they were rapidly decomposes. Based on the lignin content and $\mathrm{C} / \mathrm{N}$ ratio content, Rice (Oryza sativa) straw and Teak (Tectona grandis) were classified as low quality, where as Angsana (Pterocarpus indicus) litter, and Kirinyu (Eupatorium inulifolium) were classified as high-quality litter. Litter quality differences will result in the release patterns of different $\mathrm{NH}_{4}^{+}$thus it might be able to control the rate of nitrification [16].

\subsection{Dynamic of $\mathbf{N}$}

The length of stay $\mathrm{NH}_{4}^{+}$in soil (Table 2 and Figure 1) can be estimated by calculating the rate value of the mineralized $\mathrm{k}$ and $1 / \mathrm{k}$ stays of $\mathrm{NH}_{4}^{+}(1 / \mathrm{k})$ in soil only about 1.4 to 1.9 weeks except to litter hay reach in 2.1 weeks.

High-quality litter (Pterocarpus indicus and Eupatorium inulifolium) increase the concentration of $\mathrm{NH}_{4}^{+}$in week $6^{\text {th }}$ after the application.On the other hand, addition of low quality litter (Tectonagrandis and Oryza sativa) caused immobilization of $\mathrm{NH}_{4}^{+}$from the beginning to the end of experiment (in 10 weeks). Analysis of variance showed a highly significant effect $(\mathrm{p}<0.01)$ in the treatment of type and dose of $\mathrm{NH}_{4}^{+}$soil concentration of the litter on the soil at the various times of incubation. However, there is no real effect of incubation time on soil $\mathrm{NH}_{4}^{+}$concentrations. The addition of low quality litter (Tectona grandis and Oryza sativa) did not increase the concentration of $\mathrm{NH}_{4}^{+}$significantly difference compared with the control experiment (no litter and no urea), the average concentration of $\mathrm{NH}_{4}^{+}$about $35 \mathrm{mg} / \mathrm{Ha}$ (Figure 1).

Concentration of $\mathrm{NH}_{4}^{+}$in second week is higher than in the following weeks. In week $6^{\text {th }}$ and an increased $\mathrm{NH}_{4}^{+}$concentration in low dosage treatment of straw $(4 \mathrm{mg} / \mathrm{Ha})$, and the $10^{\text {th }}$ week on the litter of straw in high dosage (16 mg/Ha), begin mineralized. The increased of $\mathrm{NH}_{4}^{+}$concentration followed by increased of $\mathrm{NO}_{3}^{-}$

\begin{tabular}{|c|c|c|c|c|c|c|}
\hline \multirow{2}{*}{ Kinds of Litter } & \multicolumn{5}{|c|}{ Contents } & \multirow{2}{*}{$\begin{array}{c}\text { Litter } \\
\text { Quality }\end{array}$} \\
\hline & Organic C (\%) & Total N (\%) & Lignin (L) (\%) & Polyphenol (Pf) & $\mathrm{C} / \mathrm{N}$ & \\
\hline Pterocarpus indicus & 42,08 & 2.36 & 7.30 & 6.50 & 18 & High \\
\hline Eupatorium inulifolium & 10.00 & 1.58 & 20.20 & 6.40 & 12 & High \\
\hline Tectona grandis & 40.30 & 1.58 & 14.70 & 34.70 & 25 & Low \\
\hline Oryza sativa & 35.26 & 1.78 & 25.30 & 2.30 & 20 & Low \\
\hline
\end{tabular}

Table 2. Rate of $\mathrm{NH}_{4}^{+}$mineralized in soil with various additional litter quality.

\begin{tabular}{|c|c|c|c|c|}
\hline Treatment & Regression & $\mathbf{R}^{2}$ & k.week $^{-1}$ & $1 / \mathbf{k}$ \\
\hline Control & $y=-0.7392 x-0.0632$ & 0.4734 & 0.7392 & 1.4 \\
\hline Tectona grandis & $y=-0.6614 x-0.3883$ & 0.5332 & 0.6614 & 1.5 \\
\hline Oryza sativa & $y=-0.4816 x-0.3779$ & 0.4485 & 0.4816 & 2.1 \\
\hline Pterocarpus indicus & $y=-0.7011 x+0.3224$ & 0.7381 & 0.7011 & 1.4 \\
\hline Eupatorium inulifolium & $y=-0.5145 x+0.1200$ & 0.8947 & 0.5145 & 1.9 \\
\hline
\end{tabular}




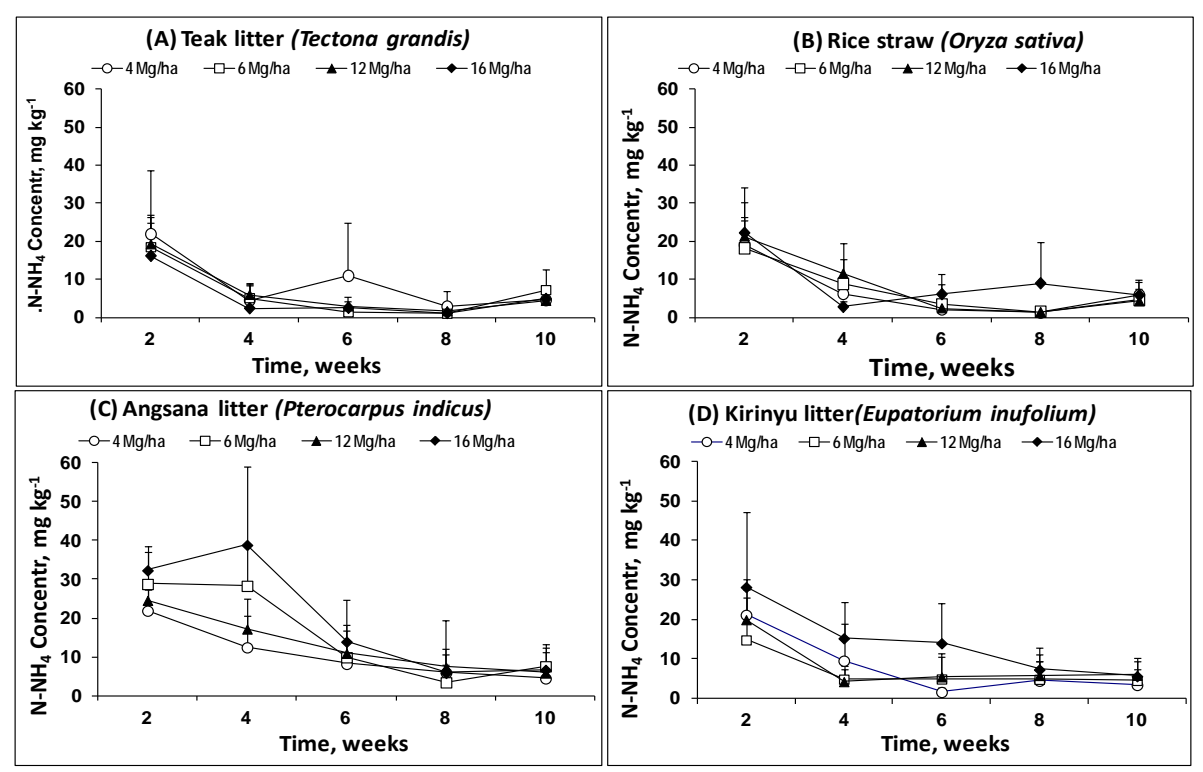

Figure 1. $\mathrm{NH}_{4}^{+}$concentration in soil (corrected with atomic weight) after the addition of various qualities and dosage of litter.

in soil with the pattern varies between species. High concentration of $\mathrm{NH}_{4}^{+}$in the early incubation (week $2^{\text {nd }}$ ) on the whole treatment thought to derive from the basic fertilizer urea hydrolysis. The high concentration of $\mathrm{NH}_{4}^{+}$on the second week also thought to derive from the basic fertilizer urea hydrolysis. In week $2^{\text {nd }}$ and $4^{\text {th }}$, litter treatment Pterocarpus indicus in high quality $(\mathrm{N}=2.36 \%$; (L P)/N = 5.8) and in high dosage $(4 \mathrm{mg} / \mathrm{Ha})$ increased $\mathrm{NH}_{4}{ }^{+}$concentration from 42 to $50 \mathrm{mg} / \mathrm{Ha}$, or increased from $90 \%$ to $361 \%$ of the amount percent in the control experiment (from 21.9 to $10.85 \mathrm{mg} / \mathrm{Ha}$ ) which only added urea fertilizer (for control experiment). However, in week $6^{\text {th }}$ after incubation, $\mathrm{NH}_{4}^{+}$concentration is declining for all treatments.

The concentration of $\mathrm{NO}_{3}^{-}$in soil is precisely the lowest concentration at week $2^{\text {nd }}$, and increased to peak in week $6^{\text {th }}$ (Figure 2). Decreasing $\mathrm{NH}_{4}^{+}$concentration accompanied by increasing $\mathrm{NO}_{3}^{-}$concentration indicated transformation process of $\mathrm{NH}_{4}^{+}$to $\mathrm{NO}_{3}^{-}$in the soil. The results of variance analysis showed that the differences in $\mathrm{NO}_{3}^{-}$concentration were highly significant $(\mathrm{p}<0.01)$ in an incubation time, dosage and type of litter given by. In various types and dosage of litter, an increase in the formation of $\mathrm{NO}_{3}^{-}$, real start in week $2^{\text {nd }}$ to week $4^{\text {th }}$ and $6^{\text {th }}$. Litter of Tectona grandis (low quality) always generates average of low $\mathrm{NO}_{3}^{-}$concentration of soil (145 mg/kg) than any other litter respectively from $219 \mathrm{mg} / \mathrm{kg}$ (Oryza sativa), $309 \mathrm{mg} / \mathrm{kg}$ (Pterocarpus indicus) and $246 \mathrm{mg} / \mathrm{kg}$ (Eupatorium inulifolium). Pterocarpus indicus treatment resulting formation of $\mathrm{NO}_{3}^{-}(893 \mathrm{mg} / \mathrm{kg})$. The higher dosage of high quality litter, the higher the amount of $\mathrm{NO}_{3}^{-}$formed.

Indicated that the process has not been held fast immobilizes $\mathrm{NH}_{4}^{+}$each section of $8 \mathrm{C}$ assimilated during the decomposition of organic matter, soil microbes need about 1 part of $\mathrm{N}$ to form the new growth in biomass (or with the ratio $C / N=8 / 1$ ). It was also stated that the whole of $C$ assimilated only about $1 / 3$ of it used to the cell builder and the rest would be released as $\mathrm{CO}_{2}$. Therefore every 24 grams of $\mathrm{C}$, the soil microbes need about 1 gr of $\mathrm{N}$ so that the addition of organic matter with high $\mathrm{C} / \mathrm{N}$ ratio $(\mathrm{C} / \mathrm{N}>24)$ into the soil will result in immobilize of $\mathrm{NH}_{4}^{+}$from the soil solution by microbes. The concentration of $\mathrm{NO}_{3}^{-}$in soil was determined by the amount of fertilizer addition of $\mathrm{NO}_{3}^{-}$or organic materials, absorption roots, microbes, and immobilization or the magnitude of the rate of nitrification in the soil [17]. Synthesis of $\mathrm{NO}_{3}^{-}$will increase in accordance with the availability of $\mathrm{NH}_{4}^{+}$in the soil. However, the increasing is not necessarily proportional to the availability of $\mathrm{NH}_{4}^{+}$, and time of occurrence of nitrification also depends on the presence of bacterial nitrification and soil conditions. Nitrification bacteria grow very slowly, so often nitrification took place after the lapse of a few days from the addition of $\mathrm{NH}_{4}^{+}$in soil [18].

\subsection{Potential Nitrification of Soil}

Potential nitrification were measured by the number of $\mathrm{NO}_{2}^{-}$formed in soil samples after enriched by 
$\left(\mathrm{NH}_{4}\right)_{2} \mathrm{SO}_{4}$ as nitrification substrates and incubated for 5 hours (Figure 3).

Analysis of variance results showed a difference of species/quality and time of incubation effect quite significant $(\mathrm{p}<0.01)$, whereas the dosage litter affect significant $(\mathrm{p}<0.05)$ against potential nitrification of soils. The increasing of potential nitrification in soils is closely connected and significantly $(r=0.802)$ increased concentrations of $\mathrm{NH}_{4}^{+}$in soil. Dynamics potential nitrification caused by adding with low quality litter is different from high quality litter. Adding low quality litter (Tectona grandis and Oryza sativa), only at very high dosage showed increasing soil nitrification potential as well as $90 \%$ of nitrification potential in initial conditions (22 $\mathrm{mg} / \mathrm{NO}_{2}^{-} / \mathrm{kg}$ /hour) with low dosage. The key to control nitrification was by controlling the release of $\mathrm{NH}_{4}^{+}$into the soil and by maintaining soil $\mathrm{pH}$ of $\mathrm{H}_{2} \mathrm{O}$ about 4.5 to 5.0. Because that liming needed to be considered, it would improve the process of nitrification in soil.

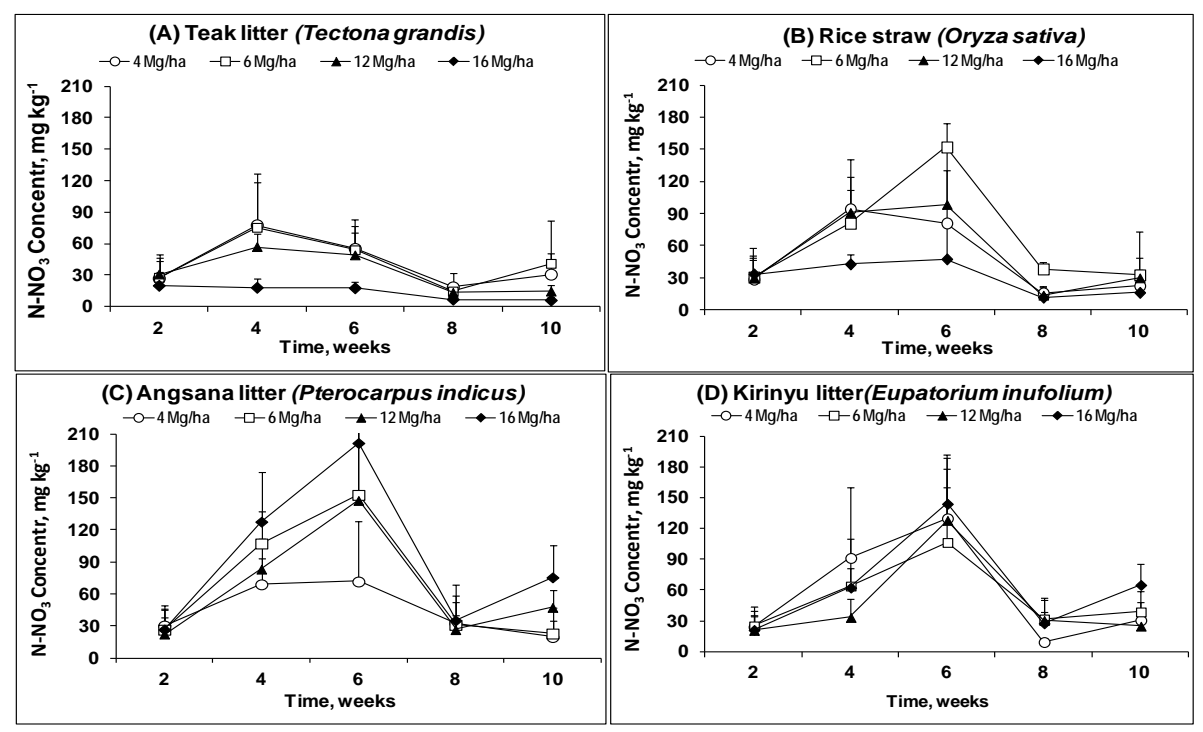

Figure 2. $\mathrm{NO}_{3}^{-}$concentration in soil after the addition of various qualities and dosage of litter.
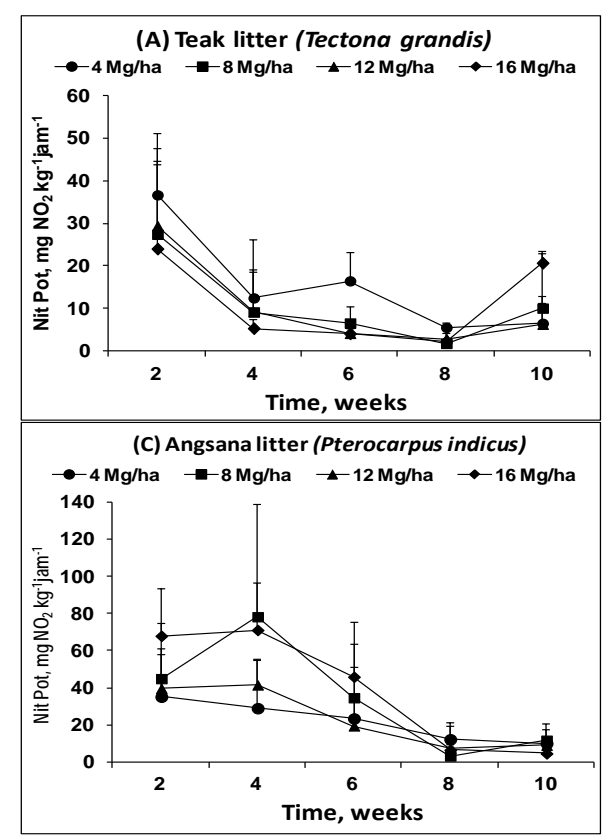

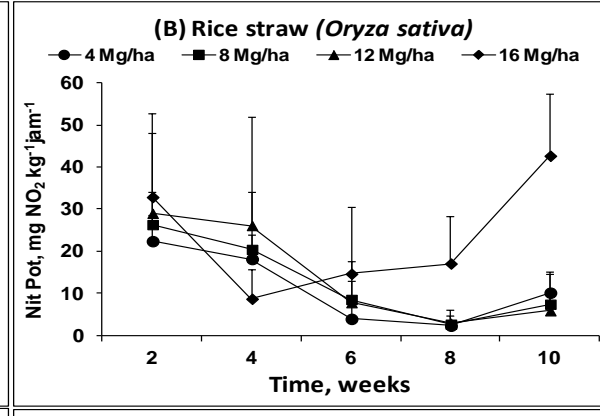

(D) Kirinyu litter(Eupatorium inufolium)

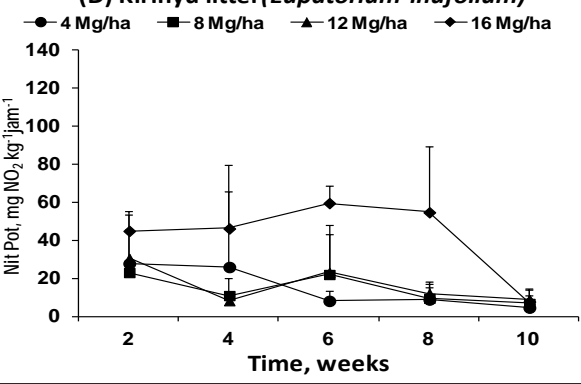

Figure 3. Soil nitrification potential after addition of various types of quality and dosage of litter. 
On the field condition, $\mathrm{N}$ which is not absorbed by the corn plant rooting potentially lost leached to the lower layers. $\mathrm{NO}_{3}^{-}$leaching will bring as well as base cations [6] [19]-[21].

\section{Conclusion}

The conclusion of this research is that the management of the quality of the litter input can be applied in the field to hinder the nitrification process of soil $\mathrm{N}$ from leaching and improving the efficiency of the utilization of $\mathrm{N}$ on corn plants.

\section{Acknowledgements}

We thank Higher Education Competitive Research Project Ministry of Education and Culture Republic of Indonesia for Grand Featured Research Mail Agreement No. 2342/UN 27.16/PN/2012 State Budget Funds and No. 159a/UN 27.11/PN/2013 and especially thank Prof. Dr. Rafik Karsidi, MSc as a Rector of Sebelas Maret University Surakarta Indonesia; Prof. Dr. Ir. Darsono, M.Si as a Chairman of the Institute for Research and Community Service; Prof. Dr. Ir. Bambang Pujiasmanto, M.Si as a Dean of Agriculture Faculty of Sebelas Maret University Surakarta Indonesia and Dr. Adi Prayitno, DDS, PhD for all kindness.

\section{References}

[1] Verchot, L.V., Hutabarat, L., Hairiah, K. and Van Noordwijk, M. (2007) Nitrogen Availability and soil $\mathrm{N}_{2} \mathrm{O}$ Emissions Following Conversion of Forests to Coffee in Southern Sumatra. Global Biochemical Cycles, 20, (In press).

[2] Van Noordwijk, M. and de Willigen, P. (1987) Root as Sinks and Sources of Carbon and Nutrient in Agricultural Systems. In: Brussaard, L. and Ferrera-Cerrato, R., Eds., Soil Biology in Sustainable Agricultural Systems, CRC Lewis Publication, Boca Raton, 71-89.

[3] Taiz, L. and Zeiger, E. (2002) Plant Physiology (Third Edition). Sinauer Associates, Inc., Publishers, Sunderland, 6786.

[4] Raun, W.R and Johnson, G.V. (1999) Improving Nitrogen Use Efficiency for Cereal Production (Review \& Interpretation). Agronomy Journal, 91, 357-363. http://dx.doi.org/10.2134/agronj1999.00021962009100030001x

[5] James, M.G., Robertson, D.S. and Myers, A.M. (1995) Characterization of the Maize Gene Sugary 1, a Determinant of Starch Composition in Kernels. The Plant Cell, 7, 417-429. http://dx.doi.org/10.1105/tpc.7.4.417

[6] Myrold, D.D. (1999) Transformation of Nitrogen. In: Sylvia, D.M., Jeffry, J.F., Peter, G.H. and David, A.Z., Eds., Principles and Application of Soil Microbiology, Prentice Hall, New Jersey, 259-294.

[7] Bardgett, R.D. (2002) The Biology of Soil. A Community and Ecosystem Approach. Oxford University Press Inc., New York, 242.

[8] Aarnio, T. and Martikainen, P.J. (1995) Mineralization of C and Nitrification in Scot Pine Forest Soil treated with Nitrogen Fertilizers Containing Different Proportions of Urea and Its Slow-Releasing Derivative, Ureaformaldehyde. Soil Biology \& Biochemistry, 27, 1325-1331.

[9] Erickson, A.J., Ramsewak, R.S., Smucker, A.J. and Nair, M.G. (2000) Nitrification Inhibitors from the Roots of Leucaena leucocephala. Journal of Agricultural and Food Chemistry, 48, 6174-6177. http://dx.doi.org/10.1105/tpc.7.4.417

[10] Paul, E.A. and Clarck, F.E. (1989) Soil Microbiology and Biochemistry. Academic Press, Inc., Waltham.

[11] Filali, A., Fayolle, Y., Peu, P., Philippe, L., Nauleau, F. and Gillot, S. (2013) Aeration Control in a Full-Scale Activated Sludge Wastewater Treatment Plant: Impact on Performances, Energy Consumption and $\mathrm{N}_{2} \mathrm{O}$ Emission. Proceedings of the 11ème Conférence IWA sur l'instrumentation, le contrôle et l'automatisation, Narbonne, 18-20 September 2013, 4.

[12] Anderson, J. and Ingram, J. (1993) Tropical Soil Biology and Fertility: A Handbook of Methods. Second Edition, CABI, Wallington, 221.

[13] Alves, J.R., Boodey, R.M. and Urquiga, S.S. (1993) A Rapid and Sensitive Flow Injection Technique for the Analysis in Soil Extract. Communication Soil Science Plant Analysis, 24, 277-284. http://dx.doi.org/10.1080/00103629309368798

[14] Kandeler, E. (1995) Potential Nitrification. In: Schinner, F., Kandeler, E., Ohlinger, R. and dan Margesin, R., Eds., Methods in Soil Biology, Spinger-Verlag Berlin Heidelberg, Berlin, 146-149.

[15] Handayanto, E. (1994) Nitrogen Mineralization from Legume Tree Prunings of Different Quality. Thesis for Doctor of Philosophy, Department of Biological Sciences, Wye College, University of London, London, 176 p. 
[16] Palm, C.A. and Sanchez, P.A. (1991) Nitrogen Release from Some Tropical Legumes as Affected by Lignin and Polyphenol Contents. Soil Biology Biochemistry, 23, 83-88. http://dx.doi.org/10.1016/0038-0717(91)90166-H

[17] Brady, N.C. and Weil, R.R. (2002) The Nature and Properties of Soils. Thirteenth Edition, Pearson Education, Inc., Upper Saddle River, 960.

[18] Tate, R.L. (1995) Soil Microbiology. Wiley, New York.

[19] Madigan, M.T., Martinko, J.M. and Parker, J. (2000) Biology of Microorganisms. Ninth Edition, Pearson Prentice Hall, Upper Saddle River, 991.

[20] McColl, J.G. (1995) Forest Clear-Cutting, Soil Response. In: Lederberg, J., Ed., Encyclopedia of Microbiology, Academic Press, Inc., Waltham, 959-1103.

[21] Wolf, B. and Snyder, G.H. (2003) Sustainable Soils the Place of Organic Matter in Sustaining Soils and Their Productivity. Food Product Press, Haworth Press, Inc., New York. 
Scientific Research Publishing (SCIRP) is one of the largest Open Access journal publishers. It is currently publishing more than 200 open access, online, peer-reviewed journals covering a wide range of academic disciplines. SCIRP serves the worldwide academic communities and contributes to the progress and application of science with its publication.

Other selected journals from SCIRP are listed as below. Submit your manuscript to us via either submit@scirp.org or Online Submission Portal.
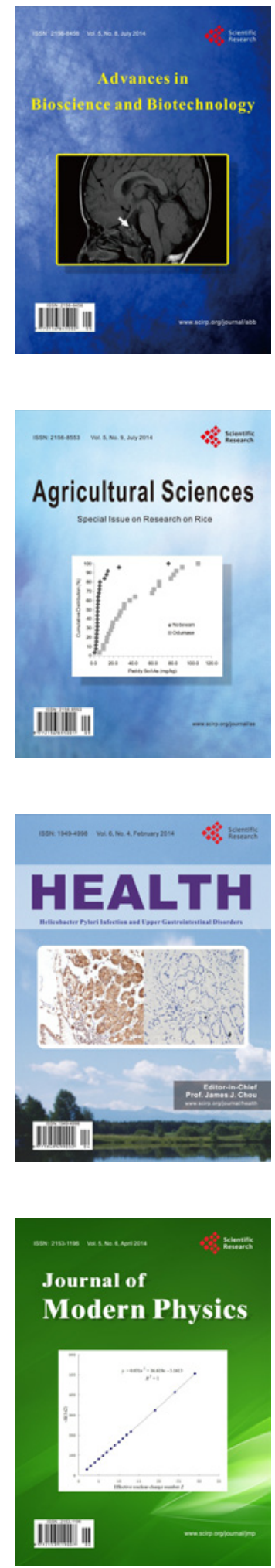
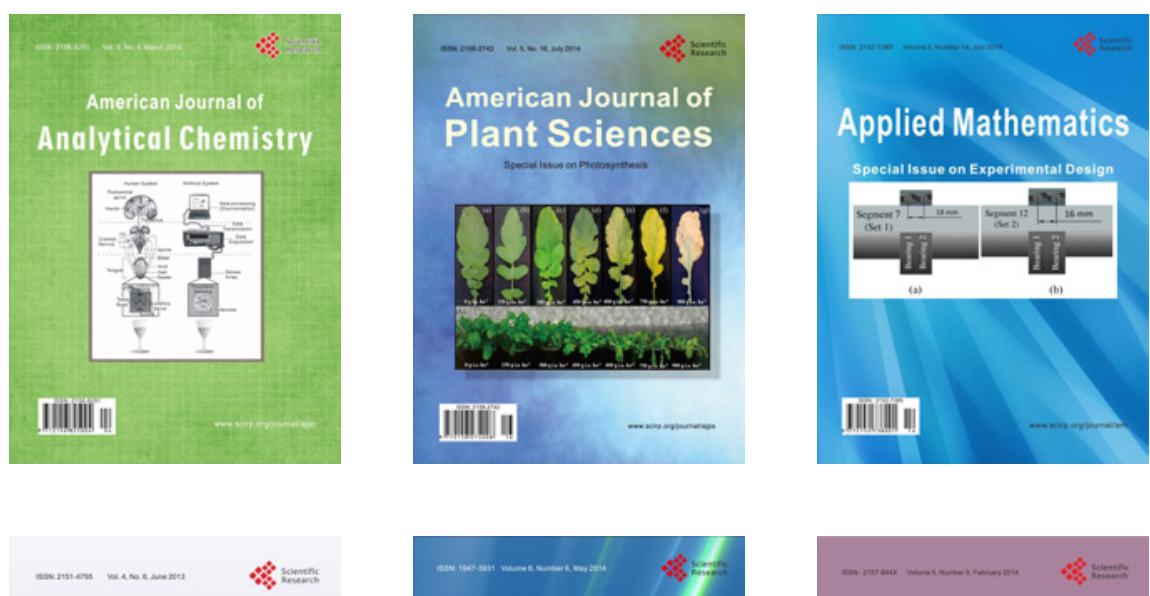

Creative Education
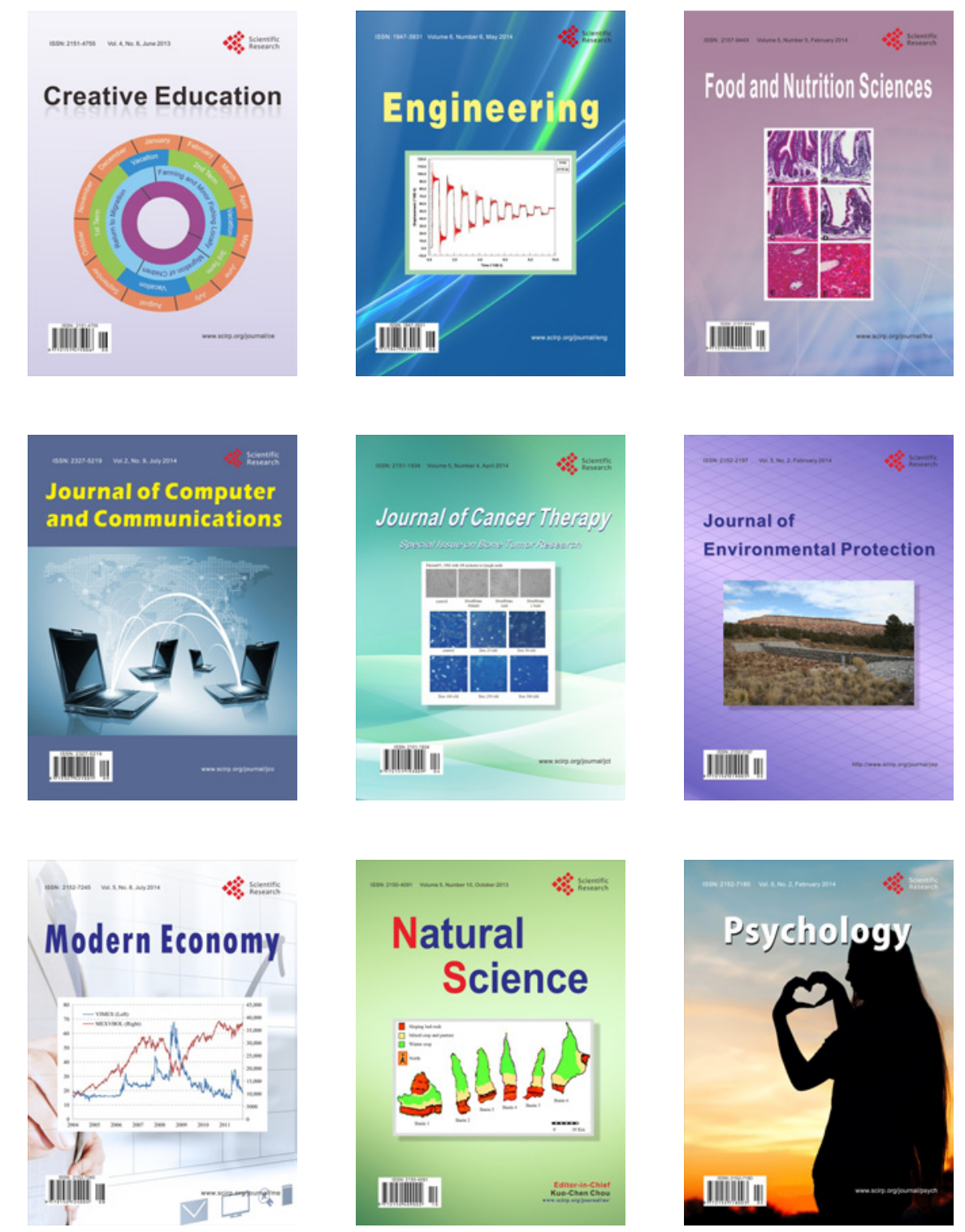